\title{
Prevalence of Stresss Ulcer Among Patients with Stroke
}

\author{
Daldiyono*, Dadang Makmun *, Yusuf Misbach**, S.M. Lumban Tobing**
}

\begin{abstract}
Abstrak
Tukak stres adalah suatu kelainan akut mukosa saluran cerna akibat berbagai kondisi patologis, misalnya tumor otak, trauma kepala, operasi otak, luka bakar, pasien dengan gagal organ ganda, strokdan lain-lain. Tukak stres pada penderita strok belum banyak diselidiki. Makalah ini melaporkan hasil penelitian prevalensi tukak stres pada penderita strok Dilakukan penelitian pada 77 penderita strok pada korteks dan subkorteks. Strok batang otak dikeluarkan dari penelitian. Diagnosis strok ditegakkan berdasarkan pemeriksaan CT scan, sedangkan diagnosis tukak stres ditegakkan berdasarkan pemeriksaan endoskopi dengan mengikuti prosedur standar. Prevalensi tukak stres pada penderita strok hemoragik 47,7\%, pada penderita strok iskemik 18,4\%, dan secara keseluruhan 33,6\%. Perbedaan antara prevalensi tukak stres pada penderita strok hemoragik dan penderita strok iskemik secara statistik berbeda bermakna $\left(x^{2}=7,02, p=\right.$ $0,0085)$, risiko terjadinya tukak stres pada penderita strok hemoragik lebih tinggi secara bermakna dibanding penderita strok iskemik dengan $O R=3,88(1,25<O R<12,44)$.
\end{abstract}

\begin{abstract}
Stress ulcer is defined as an acute mucosal lesion of the upper gastrointestinal tract caused by an indirect influence of several pathological situations such as brain tumor, severe burn, patients with multiorgan failure and stroke. Many investigators have reported the prevalence of stress ulcer among patients with stroke. This article will report the result of endoscopic examination among patients with stroke. Seventy-seven patients with cortical and subcortical stroke have been examined by means of endoscopy. Diagnosis of stroke was made by CT scan examination and stress ulcer was diagnosed by endoscopic examination according to a standard procedure. The overall prevalence of siress ulcer among patients with stroke was $33.6 \%$, i.e. $47.7 \%$ among patients with hemorrhagic stroke and $18.4 \%$ among patients with ischaemic stroke. The difference in prevalence of stress ulcer between these two groups was statistically significant $\left(x^{2}=\right.$ $7.02, p=0.0085$ ). The risk of stress ulcer among patients with haemorrhagic stroke was higher than patients with ischaemic stroke (OR $=3.88,1.25<O R<12.44$ ).
\end{abstract}

Keywords : stress ulcer, stroke

Stress ulcer is defined as an acute mucosal lesion of the upper gastrointestinal tract, predominantly in the stomach and duodenum, as a result of several pathological conditions such as brain tumor, severe burn, patients with multiorgan failure, and stroke. ${ }^{1,2,3}$ Even though the lesions of this acute mucosal damage are not always ulcerated, these conditions are still included into the term of stress ulcer. ${ }^{4}$

Stress ulcer must be differentiated from acute upper gastrointestinal lesions caused by some direct noxious agents such as salicylate and nonsteroidal anti-inflammatory drugs. 5

* Division of Gastroenterology, Department of Medicine, Faculty of Medicine University of Indonesia/Dr. Cipto Mangunkusumo Hospital, Jakarta, Indonesia

** Department of Neurology, Faculty of Medicine University of Indonesia/Dr. Cipto Mangunkusumo Hospital, Jakarta, Indonesia
Stress ulcer in stroke cases have been reported from autopsy findings by Dalgaard, ${ }^{3}$ Doig and Shafar, $\mathrm{Jura}^{7}$ and from endoscopic findings by Kitamura ${ }^{8}$ and Segawa.

We will report the results of the endoscopic examinations on stroke cases from the Department of Neurology, Dr. Cipto Mangunkusumo Hospital Jakarta.

\section{METHODS}

Seventy-seven stroke cases have been endoscopically examined. Only stroke of the cortex and subcortex were included in this study. Stroke of the brain stem was excluded because of the clinical conditions which were relatively contraindicated for an endoscopic procedure. The diagnosis of stroke was confirmed by computed tomography (CT) scan examination. 
Endoscopic examinations were performed according to a standard procedure as usual, after obtaining a written informed consent from the family.

Ethical clearance for the investigation was issued by the Research Ethical Committee of the Faculty of Medicine University of Indonesia Jakarta.

\section{RESULTS}

The result of the endoscopic examinations is reported in Table 1.

Table 1. Result of endoscopic examination on 77 stroke cases

\begin{tabular}{lc}
\hline Result of endoscopic examination & Number of cases \\
\hline Normal & 25 \\
Oesophagitis & 6 \\
Bleeding & 4 \\
Erosions : - Fundus/Body & 21 \\
$\quad$ - Antrum & 15 \\
& Duodenum \\
Hyperemia non-erosive & 4 \\
Chronic ulcer & 23
\end{tabular}

Note : More than one type of lesion may be encountered in the same case.

The description of the findings concerning stress ulcer, specified in haemorrhagic and ischaemic stroke cases respectively, is shown in Table 2 .

Table 2. Stress ulcer in 77 cases of stroke, specified in haemorrhagic and ischaemic stroke

\begin{tabular}{lccc}
\hline Type of stroke & $\mathrm{N}$ & Stress ulcer & Prevalence \\
\hline Haemorrhagic & 44 & 19 & $47.7 \%$ \\
Ischaemic & 37 & 7 & $18.4 \%$ \\
\hline Total & 77 & 26 & 33.6
\end{tabular}

$\mathrm{x}^{2}=7.02 \mathrm{p}=0.0085$ OR $=3.88(1.25<\mathrm{OR}<12.44)$

Yates' correction $x^{2}=5.80 p=0.016$

\section{DISCUSSION}

As shown in table 1 the majority of lesions were located in the fundus and body ( 21 cases), and involving the antrum (15 cases). These figures represented the characteristics of stress ulcer which have been reported in other situations such as brain operation and head trauma (Cushing ulcer), ${ }^{10,11}$ and also in burn cases (Curling ulcer). ${ }^{12,13}$

The overall prevalence of stress ulcer in this investigation was $33.6 \%$, whereas in haemorrhagic stroke it was statistically different than in ischaemic stroke $(47.7 \%$ vs $\left.18.4 \%, x^{2}=7.02, p=0.0085\right)$. The difference of the prevalence of stress ulcer between haemorrhagic stroke and ischaemic stroke cases being so significant, indicated that haemorrhagic stroke could be considered as a risk factor in the development of stress ulcer $(\mathrm{OR}=3.88 ; 1.25<\mathrm{OR}<12.4)$.

The prevalence of stress ulcer in this report differed from those reported by other investigators, Segawa ${ }^{9}$ reported the prevalence of $92 \%$ stress ulcer in stroke cases, whereas $45 \%$ of them proved to be with mucosal bleeding of the stomach. Kitamura ${ }^{8}$ in 1975 reported a prevalence of $52 \%$ for all of the stroke cases. The difference might be due to the allocation of inclusion criteria. This investigation was only done on stroke cases at the cortical and subcortical levels, whereas in the investigations of Kitamura and Segawa all stroke cases, including stroke of the brain stem, were taken into consideration.

The difference of the prevalence of stress ulcer between haemorrhagic stroke cases and ischaemic stroke cases could be explained as follows. Bleeding is always accompanied by catecholamine release, ${ }^{14}$ which promote vasoconstriction of the microcirculation of the gastric mucosa, ${ }^{15}$ and the blood in the intracranial space lead to an increase of the intracranial pressure. The increase of the intracranial pressure activate the hypothalamus-pituitary-adrenal axis and the autonomic nervous system. ${ }^{16}$

\section{Acknowledgment}

The authors would like to thank Prof.Dr. Sumarmo Markam for his permission and guidance during this investigation, and also to the nurses for their kindly help in preparing the endoscopic examinations.

\section{REFERENCES}

1. Robert A, Szabo S. Stress ulcer. In : Selye H, ed. Selye's, Guide to stress research. New York Scientific and Academic Editions, 1983; 22-46.

2. Schiessel R, Feil W, Wenzl E. Mechanism of stress ulceration and implication for treatment. Gastroenterol Clin North Am 1990; 19:101-20.

3. Dalgaard JB. Cerebral vascular lesions and peptic ulceration. Arch Pathol 1959; 69: 359-70.

4. Levine BA. Stress ulcer. In: Cheli R, ed. Gastric protection. New York : Raven Press, 1988: 13-44.

5. Robert A, Kauffman GL. Stress ulcer. In : Slaisenger, Fordtran eds. Gastrointestinal disease : pathophysiology, diagnosis, management, 3rd ed. Philadelphia: Saunders, 1975: 42-8.

6. Doig J, Shafar A. Gastric haemorrhage in acute intracranial vascular accident. Quart J Med 1956; 25: 1-19. 
7. Jura E. Gastrointestinal disturbances in stroke. Acta Neurol Scand 1987; 76: 168-71.

8. Kitamura T, Ito KL. Acute gastric changes in patient with stroke I. With reference to gastroendoscopic finding. Stroke 1976; 7: 460-3.

9. Segawa K, Nakazawa S, Chujo H. The upper gastrointestinal lesions associated with the cerebrovascular accident. Proceeding III APCDE, Taipei, 1980: 33-6.

10. Cushing H. Peptic ulcers and interbrain. Surg Gynecol Obstet 1932; 551-34.

11. Brown TH, Davidson PF, Larson MG. Acute gastritis occurring within 24 hours of severe head injury. Gastrointest Endose 1989; 35: 37-40.

12. Friesen SR. The genesis of gastroduodenal ulcers following burns: An experimental study. Surgery $1950 ; 28: 123-58$.
13. Pruitt BA, Folley FD, Moncrief JA. Curling ulcers: A clinical- pathology study of 323 cases. Ann Surg 1970; 172: 523-36.

14. Gann DS. General body response to trauma. In: Schwart GR, Safar P, Stone JH, et al eds. Principles and practice of emergency medicine 2nd ed. Philadelphia: Saunders, 1980: 164-69.

15. Omadani H, Kamisaki Y, Itoh T. Stress-induced gastric mucosal lesions and changes in amino acid metabolism due to the activation of the sympathetic nervous system in rats. Yanago Acta Medica 1991; 34(1): 37-52.

16. Feibel J, Kelly M, Lee I, Woolf P. Loss of adrenocortical suppression after brain injury: Role of increased intracranial pressure and brainstem function. J Clin Endocrinol Metab 1983; 57: 1245-50. 